\title{
An outline of a pragmatist theory on reflexivity: exploring the pathways of the concept through social theory*
}

\author{
Diogo Silva Corrêa (https://orcid.org/0000-0001-5519-6985), \\ University of Vila Velha (UVV), Vila Velha, ES, Brasil'.
}

Vittorio da Gamma Talone (https://orcid.org/0000-0003-4939-201X), Universidade Federal do Rio de Janeiro (UFRJ), Rio de Janeiro, RJ, Brasil".

Abstract: In this article, we propose an understanding of reflexivity based on the effects of degrees of indeterminacy in the most diverse situations and contexts. We conducted an analysis based on a pragmatist sensibility to outline a model of reflexivity, examining how the concept has been thought in social theory. We explore the epistemological reflexivity (Pierre Bourdieu); the tradition that associates reflexivity and personal forms of internal deliberation (Margaret Archer); approaches connecting reflexivity with devices allowing an objective apprehension of the world (Bernard Lahire); and perspectives in which reflexive action is linked to indeterminacy (John Dewey; Luc Boltanski and Laurent Thévenot). We combine routine, experiences of destabilization, catastrophe, and different high levels of reflexivity, seeking to open social theory to new research agendas on reflexive action.

Keywords: Reflexivity. Pragmatic sociology. Internal conversation. Epistemological reflexivity. Graphic technology.

\section{O esboço de uma teoria pragmatista da reflexividade: analisando os percursos do conceito pela teoria social}

Resumo: Propomos, neste artigo, a compreensão da reflexividade a partir dos efeitos de gradações de indeterminação nas mais diversas situações e contextos em que as pessoas estão inseridas. Esboçamos um modelo sobre reflexividade por meio de uma análise de sensibilidade pragmatista, pensando como o conceito tem sido mobilizado na teoria social. Exploramos a reflexividade epistemológica (Pierre Bourdieu); a tradição que associa reflexividade e formas pessoais de deliberação interna (Margaret Archer); abordagens associando a reflexividade com dispositivos permitindo uma apreensão objetiva do mundo (Bernard Lahire); e perspectivas em que a ação reflexiva está relacionada à indeterminação (John Dewey; Luc Boltanski e Laurent Thévenot). É a partir da combinação entre rotina, experiências de desestabilização, catástrofe e os diversos niveis intensivos de reflexividade que buscamos abrir a teoria social para novas agendas de pesquisa sobre a ação reflexiva.

Palavras-chave: Reflexividade. Sociologia pragmática. Pragmatismo. Investigação. Reflexividade epistemológica.
Recebido: 15.04 .21 Aprovado: 02.06 .21

\footnotetext{
* This paper was supported by Fundação Carlos Chagas Filho de Amparo à Pesquisa do Estado do Rio de Janeiro (Faperj), process E-26/202.010/2020.

I. Diogo Silva Corrêa is professor of the Graduate Program in Political Sociology, UVV; coordinator of the Laboratory of Studies of Social Theory and Change (Labemus/UFPEUVV). <dioscorrea@gmail. com>.
}

II. Vittorio da Gamma Talone is a scholarship holder postdoctoral in the Program of Postgraduate studies in Sociology and Anthropology of UFRJ.

<vittorio.talone@ gmail.com>. 


\section{Introduction}

T his article proposes to consider, firstly, on how social theory developed different approaches to reflexivity from the mid-twentieth to the beginning of the twenty-first century. We analyze how contemporary authors of social theory have addressed reflexivity and map this debate in different traditions. Beyond mapping how studies have treated the phenomenon, the goal here is to offer a comprehensive proposal to conceptualize reflexivity that, although based on a pragmatist sensibility, encompasses some of the leading social theory traditions. The assumption adopted in this study is that pragmatism (James, 1907; Dewey, 2007; Peirce, 1998) and pragmatic sociology (Boltanski, 2009; Barthes et al., 2016; Corrêa \& Dias, 2016, 2020; Corrêa, 2014; 2015; 2020; 2021; Menezes \& Corrêa, 2017) offer a heuristically valid and rich model for the current debate in contemporary sociology. Thus, our intention is not only to draw attention to the importance of a debate on the phenomenon of reflexivity for social theory but to propose new paths and new research agendas that include perspectives explored throughout this article. We propose to expand the cases addressed by pragmatism, mainly through the works of John Dewey and the pragmatic sociology of Luc Boltanski and Laurent Thévenot.

The study of reflexivity in social theory is not a new topic. It has been a central issue since the debate about social change processes in modern societies (see Beck, Giddens \& Lash, 2000; Caetano, 2013). In our view, reflexivity should be historically situated next to issues that are related to modernity, permeate the theorization of classical studies, and are intensified in the developments of contemporary social theorists. When comparing with other periods in history, we are often urged to update reflexive deliberations because $i$. we are hyper-stimulated - as pointed out by the tradition led by Simmel (2005), Kracauer (2009), and Benjamin (1985); ii. we are hyper-socialized - as advocated by Lahire (2001a; 2006), Dubet (1994), and Kaufmann (2001; 2004); iii. we live in a plural world - as pointed out by Schütz

1. We are considering reflexivity based on a western social theory and philosophical tradition. Therefore, it refers particularly to modern western societies.

2. For a discussion on the differences between social theory and sociological theory, see Peters (2015). (1945) and the Chicago School (see Joseph \& Grafmeyer, 2004); and iv. we live in a critical world - as noted by Boltanski (1990; 2009) and Boltanski and Thévenot (1991), Dodier (1991), and Chateauraynaud (1991a). In addition, v. we live amidst continuous environmental changes or "morphogenetic" structural dynamics, as pointed out by Archer (2007), Fleetwood (2008), Sweetman (2003), Adkins (2003), Adams (2006), and vi. we are often faced with risks that, amidst systemic injunctions to the individuation process (Peters, 2021), we are forced to reflect on frequently, as explained by Beck (1986) and Giddens (1991a; 1991b). The topic of reflexivity gains clear contours ${ }^{1}$ based on this set of issues related to the more general discussion of social theory and sociological theory². 
This article starts from the hypothesis that, based on the authors mentioned above, there is an inherently reflexive dimension of modern individualism. In "morphogenetic" (Archer, 2011) contexts such as those of late modernity, in which there is a detraditionalization combined with the overwhelming expansion of choices and possible definitions about the future - or about the "horizons of expectation," to use Koselleck's (2006) expression - a larger scope for personal deliberation emerges. Reflexivity is not only something individual (which is always considered) but, according to Archer (2012), reflexivity has become a systemic imperative ${ }^{3}$.

With this background assumption, we suggest thinking about the notion of reflexivity beyond the classic Simmelian conception of blasé - the mobilization of something to suppress the stimulatory excess of sensitivity. Instead of this attitude where "all things appear matted with a grey hue; [and] none is preferable to the other" (Simmel, 2021, p. 195), the "cognitive style" - to use Alfred Schütz's terminology typical of the inhabitants of modern metropolises would no longer be the operation of abstract thought at the expense of the plurality of the sensible world, but - and this is our hypothesis - reflexivity would be a kind of critical and deliberative capacity (see Habermas, 2012; Boltanski, 2009).

It is not enough for us to situate the phenomenon socio-historically. It is necessary to go a step further and deeply discuss what contemporary social theory has defined as reflexivity. Thus, we will firstly discuss reflexivity based on different traditions and perspectives. After that, we will propose a definition of reflexivity for social theory.

When considering that the notion of reflexivity refers - from the Kantian critical tradition - to a return of the subject on him or herself, i.e., the subject critically analyzes his or her own operations, it is essential to establish, within some room for variations, some traditions in sociology that have tried to delimit this phenomenon. Synthetically, we situate reflexivity in social theory in four modalities - which will be our focus in the first topics of the article, where we will briefly analyze them based on their strengths and gaps to propose our own understanding of reflexivity in the last section.

Reflexivity can be (i) epistemological when it is a methodological strategy through which the researcher makes a return on his or her own analytical operations, mitigating or becoming aware of a set of tacit assumptions inherent to his or her activity, in general, due to the position the researcher occupies in the social universe. This perspective is close to Karl Mannheim's sociology of knowledge, which proposes the use of the social world's analytical tools by individuals that objectify the
3. Although metropolitan individuals in the modern world may be more frequently urged to reflexive deliberation, this does not mean that there is a world adjusted to these deliberations. As well demonstrated in part of the work of Michel Foucault, Pierre Bourdieu, and Luc Boltanski, there are processes of domination confronting the desires of social agents with insurmountable situations. Deliberation may not mean freedom rather, it may mean the opposite. In a highly unequal context, "Reflexivity in this context does not bring choice, just a painful awareness of the lack of it" (Adams, 2006: 525). 
social world, increasing the margin of maneuver obtained when knowing or recognizing the determinations that influence the individual's own activity. We will draw on Bourdieu to develop this position of knowing the social determinations.

A second possible way of approaching the concept is observed in the tradition that associates reflexivity with (ii) personal forms of reflexive deliberation of future projects and narration of the past trajectory. Authors such as Charles Taylor, Paul Ricœur, Alfred Schütz, and Margaret Archer can be situated in this perspective. We will focus on Archer's definition of reflexivity as internal conversation.

There is also an approach that links the objective apprehension of the world, of things, and of oneself to specific devices, and writing is the most pressing example. It is about understanding (iii) graphic technologies as a possibility of more objectified apprehension of things in the world, the total situation, or oneself. We will deal with this form of reflexivity based on anthropologist Jack Goody and the sociologist Bernard Lahire.

Finally, a fourth form of approaching the concept of reflexivity is (iv) through the correlation between reflexive action and inderteminate situation found in John Dewey's pragmatist philosophy and Luc Boltanski and Laurent Thévenot's pragmatic sociology. Reflection, as an operation of intelligence, comes from the contact of the organism with an indeterminate, ambiguous, oblique, anomalous environment. Thus, reflection refers to what social actors mobilize to solve a problem (Dewey, 1938) or re-establish an agreement (Boltanski \& Thévenot, 1991).

After introducing these traditions, we propose a model for the concept of reflexivity as a tool of social theory. We advocate its comprehension as a critical and deliberative capacity that varies in intensity, ranging from a "break of daily routine" to a "reformulation of goals," or "intellectual reframing," to "extreme" and "traumatic experiences" (Pollak, 1990; Das, 2007; Talone, 2020).

\section{Epistemological reflexivity and reflexivity as a lapse}

Pierre Bourdieu introduced reflexivity as a measure of epistemological precaution into sociological reflection first in his work Homo academicus (1984) and then in his later book written with Loïc Wacquant (2001). Bourdieu assumed that interactions are always mediated by structures of objective relationships, inserting a principle of inertia into the analysis and explaining that objective structures (fields) and sub- 
jective structures (habitus) have always been transformed more slowly than interactions. Because the possibilities of the agents' perception are internalized in the form of schemes of evaluation, Bourdieu adopted the hypothesis that such possibilities are always predefined and pre-definable by structural positions. The author deduced, for example, the possible agreements, elective affinities, and oppositions - or potential attitudes from social agents - based on a chain of mediations that dialectically linked the habitus to the field, i.e., the incorporated subjective dispositions to the structured, objective positions.

In his entire theory of social space, Bourdieu was able to reconnect the behaviors of empirical agents to structural positions. Thus, sociologists are attached to the same chains of mediation to which social actors were subjected. Considering that a sociologist's opinions are related to the position in the structure of objective relations, Bourdieu drew attention to the fact that the subject of the act of world objectification - the sociologist - must recognize themselves as determined as the most common of mortals. This is why the author elaborated, in the late phase of his work, a theory of reflexivity introducing the theoretical tools of critical sociology aimed at revealing - or rather, unveiling - the tacit and implicit part of the subject's objectification work. Through the "systematic exploration of the unthought categories of thought" (Bourdieu \& Wacquant, 1992: 40), Bourdieu strove to show, throughout the process of objectification, the ways of thinking conditioned by the structural positions of a sociologist.

According to Bourdieu, habitus, fields, or symbolic violence are not concepts aimed only at determining how the social world works, but they also highlight how those who produce knowledge about the world's operation are determined - at least based on a set of trends - by their position in this same world. The author considered that (self)recognizing personal determinations would allow the sociologist to obtain a reflexive control of their objectification of the social world. Bourdieu's "objectification" of the "subject of objectification" was his bet on the possibility to obtain a minimum margin of maneuver in the face of the determinations influencing the sociologist based on their objective position in the social world.

In addition, Bourdieu's later work shows that, beyond this dimension, there is the possibility of thinking of reflexivity as a lapse. This possibility refers to cases in which there is maladjustment between subjective expectations and objective conditions. In works such as Pascalian meditations, Bourdieu loosens the rigidity and deterministic dimension of the habitus, not only recognizing the possibility of a cleaved habitus (a habitus whose socialization was produced in heterogeneous 
and incommensurable universes). In his work together with Loïc Wacquant - Invitation to reflexive sociology - Bourdieu recognizes the possibility of reflexive actions based on situations in which the crisis, the maladjustment, occurs:

[Wacquant:] Does the theory of habitus rule out strategic choice and conscious deliberation as one possible modality of action? [Bourdieu:] Not at all... Times of crises, in which the routine adjustment of subjective and objective structures is brutally disrupted, constitute a class of circumstances when indeed 'rational choice' may take over, at least among those agents who are in a position to be rational (Bourdieu \& Wacquant 1992: 131).

In a more general way, habitus has its 'blips', critical moments when it misfires or is out of phase: the relationship of immediate adaptation is suspended, in an instant of hesitation into which there may slip a form of reflection which has nothing in common with that of the scholastic thinker [...] [but] like the tennis player re-enacting a missed shot (Bourdieu \& Wacquant 1992: 131).

These passages show how Bourdieu started to recognize the existence of reflexivity in the face of possible situational disorders and relations of maladjustment between the body and the world. On the other hand, it must be emphasized that the French sociologist did not develop a theory of reflexive action or reflexivity in this area. His entire theory of reflexivity was restricted to the case of sociologists who take their own position in the social world as an object and tries to produce a (self) objectification to analyze the tacit assumptions of their own activity. Bourdieu's theory granted lay actors only this kind of proto-reflexivity or reflexivity as a lapse, a condition quite limited to exceptional situations and short-term maladjustment.

\section{Reflexivity as an individual project or the narrative of a life}

After the epistemological form of reflexivity addressed above, this section discusses the second form, which is related to how the individual reflects on the meaning of life and introduces this meaning into action. This form of reflexive action can be approximated to Ricœur's concept of narrative identity (Paul Ricœur, 1994; 1995a; 1995b; 1997), understood as the means through which a field of renegotiation and reiterated reinvention of a biographical trajectory is established. Also, this form of reflection can be approximated both to Charles Taylor's (1989) notion of the hermeneutic self - conceived from the idea that human beings are self-interpreting animals - and to the concept of internal conversation developed by Margaret Archer (2000; 2003; 2007). To keep this article to a reasonable length, the study emphasizes Archer's work. The author points to how individuals, through internal 
conversations, adjust their respective course of action to their ultimate concerns. Contrary to the perspective of Bourdieu and Giddens, who sought to dilute the relationship between agency and structure in the realm of current action and practice, Archer takes up the distinction by thinking of action and structure as entities linked to distinct ontological levels.

For the British sociologist, dialectizing structure and agency, as proposed by the authors above, would be the same as the social structure colonizing the individual agency such as in the form of a neo-objectivism (Peters, 2013), producing what Archer (2003) calls "fallacy of conflation." Archer includes the internal conversation between structure and agency. It is a conversation through which these two dimensions are mediated. Without predicting forms of determination of one over the other, the internal conversation tries to guarantee the autonomy of each ontological level, asserting that the relationship between them is never one of conditioning or determination. In the author's words, "to stress the importance of reflexive deliberation is to allow that personal subjectivity filters how agents respond [differently] to the same objective circumstances" (Archer, 2003: 135).

Therefore, Archer argues that all active social structure is filtered or pass through the scrutiny of individual reflexive deliberation. The structure does not condition individual actions or thoughts. On the contrary, through the internal conversation, thoughts reflexively elaborate projects and autonomously decide the best course of action. The author attributes three properties to the internal conversation that guarantee it as an independent instance, free from structural constraints: "the internal conversation is held to be $(a)$ genuinely interior, $(b)$ ontologically subjective, and (c) causally efficacious" (Archer, 2003: 16). Social and cultural structures are related to situations. They are not related to the agent or imprinting on the agent their mark or shaping his/her tastes and preferences, as in Bourdieu's famous book Distinction. At this point, Archer insists that:

\footnotetext{
Shaping our situations such that they [social and cultural strucutures] have the capacity to operate as constraints and enablements [...]. Thus it is not agential properties that interact directly with social powers, rather, it is the projects formulated by agents, in exercising their subjective and reflexive mental powers that do so (Archer, 2003: 132-133)
}

Indeed, agents occupy a position in the social structure, but this position does not imply a relationship of preconditioning or determination. Agents single out the position occupied as they act according to their ultimate concerns. Structures are not in bodies or minds but in situations, revealing themselves as enablements and con- 
straints on the projects that social actors stipulate for themselves. Based on these general characteristics, Margaret Archer summarizes her model as follows:

(i) Structural and cultural properties objectively shape the situations that agents confront involuntarily [...]; (ii) Subjects' own constellations of concerns, as subjectively defined in relation to the three orders of natural reality: nature [e.g., health], practice [e.g., sport, work] and the social; (iii) Courses of action are produced through the reflexive deliberations of subjects who subjectively determine their practical projects in relation to their objective circumstances (Archer, 2003: 17).

Thus, Archer understands reflexive deliberation as the means to define and distinguish ourselves as human agents. In everyday life, because we are reflexive and self-interpreting beings, we permanently question our lives and ask ourselves how to bring our course of action closer to what we consider essential to our lives. These concerns are arranged in three orders: "concerns about our physical well-being in the natural order, about our performative achievement in the practical order and about self-worth, in the social order" (Archer, 2003: 120). The internal conversation is the mean through which we distribute these three orders and direct them to what we consider to be (our) good life, finding "our way through the world" (Archer, 2007) and consolidating our way of being.

The author considers subjectivity an internal personal property, relying on a

4. In addition, Archer $(2000 ; 2004)$ includes emotions as part of "[internal] commentaries on our concerns," i.e., emotions make up our "internal deliberations." They would tell us how much we affect ourselves and how we are doing regarding concerns: emotions "transmit us the importance of the situation" (Archer, 2004: 31). And they could be "fixed" as they involve fallibility. first-person subjective ontology, with causally effective powers in relation to itself and society. Also, exercising the personal reflexivity capacity is deliberating about oneself in relation to his or her circumstances to plan future actions. However, as observed before, not all social influences can be under the radar (Archer, 2010), even with a high proportion of internalized sociability. The self is emergent, relational (between the body, nature, and practice), and enjoys internal reflexive freedom (Chalari, 2009).

For Archer, more than just reflecting, we are inherently and viscerally reflexive beings ${ }^{4}$. It is human to be in permanent reflection. Reflexivity is a potential competence, and every human being (albeit unevenly) is equally capable of developing it. We use reflexivity at all times, elaborating individual projects, giving meaning to what we do, and, therefore, placing all structural and situated constraints under the scrutiny of this capacity. 


\section{Writing as a device of reflexive apprehension of the world}

As observed above, the second form of reflexivity is linked to the capacity of subjectivity to impose meaning on action through the elaboration of individual projects. This section addresses the third form, which shifts reflexivity to the dimension of devices, in this case, writings, texts, and graphic technology as supporting elements to achieve a more reflexive apprehension of reality.

Goody, in his famous study on graphic reason, reflects on a particularity of writing, of the graphic knowledge (Goody, 1977: 8), stating that:

\footnotetext{
writing puts a distance between a man and his verbal acts. He can now examine what he says in a more objective manner. He can stand aside, comment upon, even correct his own creation - his style as well as his syntax (Goody, 1977: 150).
}

As a graphic technique that allows access to representations and totalization instruments, writing can be understood as a technique of objectifying reality. Once this technique is mastered, it modifies the practice itself: "once introduced in the written context, the reflexive attitude has been imposed on the oral composition itself" (Ibid.: 260, our translation). As the French sociologist Bernard Lahire points out:

writing practices are true disruptive actors vis-à-vis the practical sense. They constitute acts that break with the practical logic of conducting practices based on the evidence of things to be done, breaking the practical sense actualized in the urgency of practical action (Lahire, 2001b: 153 our translation).

Graphic technology modifies our relationship with time and space. It allows a break with the urgency engendered by the temporal flow of practical action and enables a more reflexive apprehension of our behavior.

According to this tradition of reflexivity, having graphic technology means reconfiguring the relationship with practical sense, with the natural and spontaneous flow of action. If writing can give "oral communication a semi-permanent form" (Goody, 1977: 86), it may, on the other hand, interfere with how this practical sense will be (re)established. Once writing is introduced, the practical relationship with practice is reconfigured, since, from then on, it is possible to establish the "rules of good speaking (grammar), good thinking (logic), models of good speech (rhetoric), the text of the prayer or poem recited" (Goody, 1977: 13). 
In the same direction, in his work L'Homme pluriel, Lahire analyzed how the teaching of writing at school introduces a new form of language apprehension. If before, individuals were involved by language and only used it as an instrument or vehicle of will or thought, with the entry of writing into the practical regime of action - particularly with the elaboration of a prescriptive grammar - they increase the level of control over what they do and have a set of resources that allow them to have a more objective apprehension about things and about the world. For Lahire:

to objectify a language is to submit it to radical ontological change: the child was within their language. The child then faces the language, observes it, cuts it, underlines it, classifies it, arranges it in categories (Lahire, 2003: 178, our translation).

Writing engenders a set of novelties that alter our relationship not only with language itself but with the world. One example is a shopping list, which works as an instrument for ordering tasks while it is linked to cognitive processes that indicate the possibility of planning the action. From this point of view, the list is a hierarchical way of organizing behavior and, therefore, an element that leads to reflexive apprehension of reality.

Also, since writing works as a "totalization tool" (Goody, 1977:14), Lahire points out how it helps us elaborate a more accurate action. According to the author, it is possible to better "rationalize," i.e., planning the conduct and action, through writing. The graphic technique engendered by writing allows a two-dimensional and abstract apprehension of what until then was a three-dimensional and concrete relationship with the world of life.

For Goody, "the graphic projection allows the agency of meanings in another way, in a two-dimensional space" (Goody, 1977: 11). Thus, the graphic technique can summarize the complexity of reality and work as an orientation tool that engenders a set of coordinates, such as, for example, in classifications of cards, in synoptic tables. Not only that, personal diaries and autobiographies, for example, allow, according to Lahire, "to return on the past action, to give it meaning, extend it, follow the ongoing action, or prepare the future action" (Lahire, 2008: 172).

Lahire and Goody show how this third form of reflexivity is related to the reflexive apprehension of the self and the things arranged in the world, to the technique of writing and the graphic technologies accessed through writing. 


\section{Reflexivity in critical situations and beyond the lapse}

In this section, we show how pragmatic sociology inserts reflexivity into the situation. From the perspectives of philosophical pragmatism and pragmatic sociology ${ }^{5}$, reflexivity refers to the elements that emerge when an organism is faced with indeterminacy in its surroundings. This approach will be analyzed through the pragmatist philosophy of Dewey and the pragmatic of ordinary judgments by Luc Boltanski and Laurent Thévenot. It understands reflexivity as a modality of intelligence that emerges amidst doubt and anomaly, in a close association between reflexive action and the indeterminate situation (Dewey, 1938) or the critical moment (Boltanski \& Thévenot, 1999).

Edmund Husserl's phenomenology and Schutz's phenomenological sociology (1979) portrayed the idea that there is always an available world that precedes us and works for as a typified reference scheme. When we come into the world, we are faced with a permanent ontological structure of the "original world" in which reflection is diluted in practical action, as an agency-immersed-in-the-world. In this practical type of action, the entities we engage are spontaneously accepted and validated by tacit perception.

When immersed in routine situations, it is possible to say that we are under a practical orientation regime. The action in common focuses on tasks to be performed with the support of reference points, landmarks (repères) available in the environment, and the body (Thévenot, 2006). Such reference points can be internal - those in the body such as dispositions and bodily habits - or external - expressed in devices, i.e., material or symbolic objects that help coordinating individual or collective action (such as traffic lights, clocks, laws, signage, maps). The different perceptions and interpretations of these reference points may vary quite widely without disturbing the interpersonal relations.

As Garfinkel (1967) showed when discussing the "breaching experiments," trust is the feeling that best defines the state of bodies in this regime. Therefore, the doxic regime or the routine and habitual action present a tolerance in the face of small disturbances, failures, and anomalies. For Luc Boltanski:

people actively cooperate to keep away from threatening anxieties, ignoring the differences in interpretation of what is going on. Above all, they turn a blind eye to the failures that may cause uncertainty (Boltanski, 2009: 99).
5. For more on

differences,

proximities, and direct and indirect legacy from the American pragmatism to the French pragmatic sociology, see Cefa and Joseph (2002) Corrêa (2014) and Corrêa and Dias (2020). 
However, we are not always retained and limited to the practical account of the action. A flaw of an unbearable intensity or size forces us to take it as an object of reflection. When the body's habitual automatism or the inter-objective arrangement of things are no longer able to "cope with the situation," i.e., to restore normality, there is a qualitative change in the nature of the situation. In order to solve the problem - and, before that, problematize the indeterminacy - a reaction from the people directly affected is imperative. The break with the practical regime of action culminates with the emergence of a regime that establishes reflexivity. According to Boltanski, it is about the transition from a diluted action regime to a regime of intensified reflexivity

\begin{abstract}
where the participants' attention shifts from the task to knowing how to assess what is happening. The participants' attention is oriented toward the common action itself, its modalities, conditions, the forms in which the common action is manifested. What one is doing [...] seems no longer obvious. And even if [...] the appearance of an agreement is not under debate, attention and energy turn to what has to be done, to face the urgency of reality, moving toward [...] knowing what to do and how to act so that the designated task is actually carried out (Boltanski, 2009: 107).
\end{abstract}

The reflexive regime, breaking with practical sense, separates an ideal situation from the situation that actually happens. It is possible to perceive an unevenness between the actual situation and what was expected to happen because of disarray or indeterminacy due to a separation between the actual state of things and the symbolic forms. Such separation is carried out at the cost of leaving the regime of practical engagement. Reflexivity then emerges from this gap. However, it is necessary to know the forms of reflexive action that start from the break with the practical engagement.

The work of Boltanski and Thévenot is situated in the pragmatist tradition and approaches a theory of problematic situation supported by Dewey's pragmatism. It is possible to say that part of Boltanski's work, both in L'amour et la justice comme compétences (1990) and De la justification (1991), written with Thévenot, is oriented toward indeterminate situations that invite agents to produce an axiological inquiry aimed at situational re-stabilization - the agreement - either through criticism or justification. Limited to exploring the justification regime, the authors' work deals with situations in which a crisis occurs - inter-objective (for example, a computer failure, a light that suddenly goes out, the failure of a machine in the production line) or inter-subjective (such as personal offenses, interpretation disagreement, intellectual quarrels) - and individuals are obliged to carry out an axiological inquiry to find a consensus to disagreements, or equilibrium to the situation. 
In disputes that involves justice, the authors demonstrate how people perform a reflexive movement inwards, reconstructing experiences, establishing stories, narrating experiences within justifications. The actors look, analyze, and refer to the past, seeking to find situations/moments/events that allow the construction of judgments about the present in which "something went wrong" (Boltanski \& Thévenot, 1999) ${ }^{6}$ while also projecting on future situations.

The work by Boltanski and Thévenot could be read in this sense, more specifically in the situated focus, observing the critical moment, demonstrating and pointing out the moment in which critical competence is set in motion. For the authors, critical or reflective competence only makes sense if, and only if, it is taken inseparably from the occurrence of a problem, a failure, a trouble, more precisely when the situation is no longer subject to immediate, tacit understanding, requiring new justifications and criticisms to establish a new agreement ${ }^{7}$. Critical capacity, considered a synonym for the reflexive regime, is understood as the moment of test, i.e., "the moment of uncertainty about the state of affairs" (Chateauraynaud, 1991b: 166; see Corrêa \& Castro, 2016; 2020; Corrêa, 2021). In this configuration, beings and their respective statutes and qualifications, mutual relations, and social order can be reevaluated and transformed. It is a moment of uncertainty about a specific state of affairs, leading to a new agreement about the world.

\section{Outline of a pragmatist theory of reflexivity}

We examined the concept of (i) epistemological reflexivity, addressing the moments in which the researcher returns to their own analytical operations to reveal the tacit assumptions inherent to their activity. Then, we approached the tradition that (ii) associates reflexivity with personal forms of reflective deliberation of future projects and narration of the past trajectory. Third, we presented the approaches (iii) relating reflexivity with devices that allow an objective apprehension of the world, of things, and oneself, the most explored example being writing and "graphic reason" (Goody, 1977). Finally, (iv) we discussed a form of reflexivity based on the perspectives of Dewey and Boltanski, and Thévenot. In this section, we introduce a concept able to encompass and embrace the contributions of these perspectives, operating at the interface of routine (habit) and catastrophe (trauma).

With the pragmatist tradition, we assume that, in general, reflexivity is updated, above all, in situations where there is a break, a disruption, a trouble in the ordinary situation. To allude to Harold Garfinkel and his breaching experiments, in social theory, it is possible to say that the ideal correlate of reflexive action is proportional to a breaching experience, in which there is a mobilization of the agency to overcome
6. A study of the possible ways of making memory effective in these terms (Talone, 2020) can be carried out based on events and devices (material or not) that the actors mobilize to refer (interpreting or reinterpreting) to the past (Barthes et al., 2016).

7. According to Boltanski: "when it is hard to reach an agreement people must clarify their positions regarding justice, conform to an imperative of justification and, to justify, they must withdraw from the immediate situation and ascend to a generality (montée en généralité). They are oriented, then, toward a position that rests on a principle that is valid in all generality, i.e., a principle whose claim is conferred by a universal validity" (Boltanski, 1990: 74, our translation). 
a crisis or anomaly. In this hypothesis, actors in ordinary life pursue the following trend: the greater the intensity of the disarray they encounter, the greater the propensity and efforts to generate an equivalent reflexive intensity as a correlate. Figure 1 summarizes this perspective on the concept.

FIGURE 1

POSSIBLE DEGREE OF CORRESPONDENCE

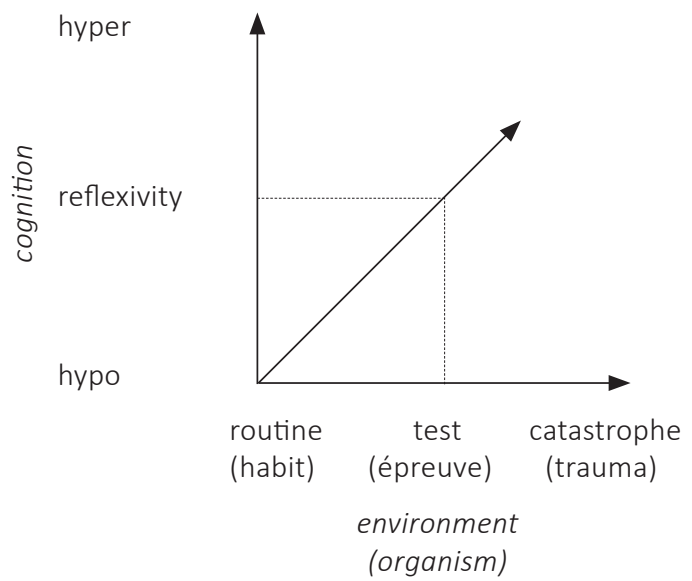

As seen in Figure 1 above, there is a essential pragmatist thesis considering a trending correspondence between indeterminacy and inquiry or reflexivity.

However, it is possible to propose a model exploring the fact that this process has a limit. As we saw in Dewey (1938), the organism, faced with a problem, can overcome it through the use of its reflexive intelligence, but (absent in this author's work and added here) the organism can also succumb to it. Therefore, routine -i.e., when reflexivity is in a latent state (and not entirely absent) - must be challenged by catastrophe - which is the state where routine is not operating and siderated (see Stavo-Debauge, 2012). In our view, it is imperative to go beyond the correlation established by pragmatism, including variations in which reflexivity does not necessarily fit with critical moments or moments of a test, as proposed in Figure 2.

From these combinations among routine, test (épreuve), breaching experience, catastrophe, and the various intensive levels of reflexivity from hypo to hyper, it is possible to build a more comprehensive and complete model of reflexivity for social theory, opening the concept to new research agendas that include and expand the perspectives explored above.

There are three possible paths or dimensions to approaching the different forms and levels of reflexivity. They are $i$. a sociology of routines, dispositions, and habitu- 
FIGURE 2

INTENSIVE LEVELS OF REFLEXIVITY

\begin{tabular}{|c|c|c|c|}
\hline & Hiporeflexivity & Reflexivity & Hiperreflexivity \\
\hline Routin (habitus) & $\begin{array}{l}\text { Pratical sense } \\
\text { (Bourdieu) }\end{array}$ & $\begin{array}{c}\text { Shopping list, sypnoptic tables, } \\
\text { personal diary } \\
\text { (Goody and Lahire) }\end{array}$ & $\begin{array}{c}\text { Method of epistemic } \\
\text { precaution } \\
\text { (Bourdieu and Wacquant) } \\
\text { Alert launchers, surveillance } \\
\text { policy } \\
\text { (Chateauraynaud) }\end{array}$ \\
\hline $\begin{array}{c}\text { Épreuves } \\
\text { (Test) Trouble }\end{array}$ & $\begin{array}{l}\text { Micro-troubles/maladjust- } \\
\text { ments, lapses between body } \\
\text { and environment } \\
\text { (Bourdieu and Wacquant) }\end{array}$ & $\begin{array}{c}\text { Breaching experiences, critical } \\
\text { moments } \\
\text { (Garfinkel; Boltanski and } \\
\text { Thévenot) }\end{array}$ & $\begin{array}{l}\text { Internal conversation } \\
\text { (Archer) }\end{array}$ \\
\hline $\begin{array}{l}\text { Catastrophe } \\
\text { (trauma) }\end{array}$ & $\begin{array}{c}\text { Paralysis, sideration } \\
\text { (Das, Pollak and Caruth) }\end{array}$ & $\begin{array}{c}\text { Experiences in concentration } \\
\text { camps, traumatic events } \\
\text { (Pollak and Das) }\end{array}$ & $\begin{array}{c}\text { Compulsion, paranoia, } \\
\text { obsessive neurosis } \\
\text { (Boltanski and Peters) } \\
\text { Radical self-reconfiguration } \\
\text { (Caetano; Pollak and Das) }\end{array}$ \\
\hline
\end{tabular}

al actions; ii. a sociology of controversial situations, critical moments, and moments of test; and iii. a sociology of catastrophic or traumatic situations. Although they explain phenomena of different orders, the proposed agendas compose a body of situations, events, and conjectures that can be interspersed and make up social life together. Therefore, we aim both to indicate paths for a more accurate understanding of the different intensive levels of reflexivity and explain the individuals' possible transitions or trajectories among these paths. This movement requires some clarification.

The first issue that deserves clarification is to think about hyporeflexivity and hyperreflectivity in the habit and routine regimes. It is in this sense that we can conceive academic careers or specialists' (experts) activities, in which the actor's usual profession aims the systematic development of reflective faculties, i.e., for the frequent problematization and updating of the critical apparatus directed toward situations that, for a layperson, are in perfect harmony. Another example is the sociology of alerts. Francis Chateauraynaud approaches reflexivity in his work with Didier Torny (1999), discussing surveillance and characterizing "anticipation policies." The authors use whistleblowers, actors who observe serious problems while denouncing authorities' inability to notice or avoid them, apprehending and communicating dimensions of reality that would be "invisible" to most people or institutions. There would be a whole particular sensory experience implied in the ordinary experience of perceiving risk and carrying out surveillance, as it implies precaution, "traceability," and the permanent state of mistrust. The alert appears as an attempt to establish an unfulfilling prophecy [prophétie déréalisatrice], a statement about an annihilated future, seeking to instigate society to "play ahead" due to crises that arise in new and unthinkable ways, requiring constant reflexivity. 
The academic, the expert, and the whistleblower are those who, in their most routine and habitual action, engage in the production and anticipation of problems and issues that are not necessarily updated in the present situation. What we have shown based on epistemological reflexivity can be put in these terms: it is the production of a reflexive apprehension of the self - a process of "objectification of the subject of objectification" - which takes place within a habitual perspective. We can think the same, with Lahire and Goody, about the reflexivity instituted by socio-technical devices, such as graphics and shopping lists. Following their course of action from a list written before leaving home, a person in the supermarket cannot be considered submerged in a problematic situation where there is a break with the usual and routine regime of action. On the contrary, for many of us, going to the supermarket is part of our weekly routine. In this case, if it is true that reflexivity is not absent, a concept that escapes the parameters of the pragmatist perspective establishes a correlation between reflexivity and problematic situation or evidence.

Concerning test situations, we can think of an increasing scale that goes from micro-adjustments (the "lapses" described by Bourdieu and Wacquant) to the destabilization experiences explored by Garfinkel and by the pragmatist tradition to the internal conversation of Margaret Archer. Internal conversation can be thought of both as a capacity (in this case, it would be in the habitual regime) and as a competence aimed at solving existential problems about what to do to achieve the "good life" or reach the "ultimate concerns." In this sense, we can expand the concept of the problematic situation - or even the concept of 'situation' - to problems that can be both intersubjective (as in the case of disputes and critical moments discussed by Boltanski and Thévenot mentioned above) and intrasubjective (such as the search for a harmonious adjustment between the individual course of action and the narrative coherence of oneself, as Paul Ricœur would say). Thus, we stipulate the concept of Archer as a modality that takes place in dealing with problematic situations, in this case, intrapsychic issues (see Corrêa, 2020).

But the reflexivity established by the second tradition, in our view, can be included within a correlation between reflexivity and habitual regime. We can also understand the concept of reflexivity as referring to a problem whose duration is relative to the experience of individual subjectivity. Therefore, the derailment (inter-objective, inter-subjective, intra-subjective), which urges individuals to disengage from the prosaic situation of the world of life and forces them to reorient their attention on (or to focus their reflexive attention on) certain aspects until then ignored or relegated to the automatisms of habit relating to bodies or routine relating to the inter-objective organization of the environment, it is not reducible to a specific situation. This experience of crisis can therefore be trans-situational. 
Finally, we can talk about the modes of reflexivity that can be thought of in light of a regime of catastrophe and trauma. This regime can be associated either with a state of hyporeflexivity - represented by the moment when there is a shock and/or denial in relation to the experienced event, followed by the state of sideration (see Pollak, 2006; 2010; Caruth, 1995) - or a state of hyperreflectivity - which can take the form of obsessive neurosis, paranoia, or reflexive compulsion (see Peters, 2017, 2019; Boltanski, 2012) - or radical reconfiguration of the self.

Boltanski and Peters address the actors' "delusion with reality," or how institutions and disciplines interpret reality. This issue concerns the different possible ways of conceiving what the "true reality" is and the effects of a mismatch with the more stable or universally accepted "graps" (prises) (Chateauraynaud, 2011) of the "real," leading actors to paranoia or neurosis. Boltanski (2012) shows how the first adherence was invented by psychiatry at the beginning of the twentieth century. One of the main symptoms was the tendency to undertake endless inquiries and prolong them to the point of delirium. The term translates a way of problematizing reality and working the contradictions that inhabit it perennially.

Peters (2017) also seeks to explain the contents of perception related to the transformation of the "atmosphere" that characterizes perception in a way that individuals experience a deep disconnection with the world and with others. In several cases, the individual goes on to hyper-reflection as a "delusional" way of interpreting the real, but not by mistakenly "disconnecting" from it; but representing the real in a delusional way to make sense of the previous loss of their sense of reality - the previous "disconnection" by the transformation of the "atmosphere." Caetano (2013) stated that these are events that can lead to the restructuring of mental schemes. The way each person thinks about themselves can change throughout their lives according to changing circumstances, contexts, and experiences. The mismatches between the ideals of a person and those of their family may be enough to make them rethink their life, adapting the path.

William James (1890) showed us how a person has as many social selves as individuals recognizing and having an image of this person in their minds - and these selves are managed in different ways ${ }^{8}$; authors such as Ana Caetano, Michael Pollak, and Veena Das show how "extreme events" can be disruptive to self-understanding, and can lead people to "shock" and/or to explore and reflect on their own narratives and "biographical situations" (Schütz, 1979) - is a transition that can occur over time and under the support or not of "affective communities" and support groups (Pollak, 1990; Talone, 2020). Self-transformation, as Archer (2010) puts it, can occur daily through a reflexive "internal conversation" - effective in almost all
8. According to James (1890), the "total self" is everything causing the same emotions in a person. This

"total self" consists of the following selves: the material self, the social self, the spiritual self, and the pure self. In this sense, Charles $\mathrm{H}$. Cooley (1902) points out that, for James, self designates "all things which have the power to produce in a stream of consciousness an excitation of a certain peculiar kind" (Cooley (1902: 138). It should be noted that we refer to James because his work is relevant in discussions of the self, but we adopt his contributions critically. 
humans - in which people seek to conform to their (new) concerns, ideals, or ultimate commitments; but the "survivors" of different and serious types of violence have their own forms of inquiry, aiming for new ways of living, other ways of being (of sustaining their selves), and of outlining new motivations and goals.

After "extreme experiences" (Pollak, 1990; Das, 2007; Talone, 2020), the "I" clashes with the "routinized me," as usual responses are no longer appropriate and must give way to different actions. New selves suddenly or urgently ask for space - a process composed of a certain intensive degree of reflexivity. Also, the same person can go from "shock" and "paralysis" in relation to their own actions to the complete restructuring of their selves (of what shapes them) and ways of getting on with life.

In this sense, Das $(2003 ; 2007)$ highlights the work of a self to exist in a "habitable everyday life" and not in the "ghostly past" of the experienced traumatic event. Self-creation in everyday life is recognized as a careful and precise "regrouping of life." It is "awareness-raising" (Cefaï, 2009) that induces a new experience of the environment, of oneself, and of the other, and the trouble gradually becomes more specific - the consequences of a change or the effects of a context is delimited, re-elaborated, and a measure is taken. There is a degree of reflexivity through which people and groups think and process explanations about themselves, interpreting themselves (in Taylor, 1989) in other terms, building versions of their lives in a movement of self-knowledge also being a kind of self-construction - it can come out of "disabling grief" or "denial" (Talone, 2020).

To conclude the article, although we defend that "problematic situations" arise from breakdowns or troubles that occur in situ, it is not to say that problems end in situations in which they were generated or, even, that problems always refer to current situations. Therefore, we believe it is necessary to establish a separation between different forms of indeterminacy and to oppose the tolerable indeterminacy of the practical sense to the situated indeterminacy of the pragmatists. And two other forms of indeterminacy must be added, namely, the durable, which is intersubjective and can be expressed in terms of what we above called affaire or controversy; and the mental, produced internally, expressed well by Archer's internal conversation. Indeterminacy, in this case, can be of an imagined order - in the sense of anticipation - and then not be circumscribed or updated in a specific situation. 


\section{Final considerations}

This article explored the tools offered by different traditions of social theory to address reflexivity in different ways and propose another understanding of this concept. We added a variation of indeterminacy and intensity to the core notion of reflexivity, a variation related to habitus, routine, to a "break" of daily/breaching situations, experts activity, and, finally, the reformulation of the self, which a person or group achieves following "extreme experiences" - they may have gone through a "paralyzing shock."

This article examined the different forms of reflexivity. The epistemological reflexivity explored based on Bourdieu; the reflexivity as personal forms of reflective deliberation of future projects and narration of the past trajectory, based on Archer; the reflexivity as devices allowing an objective apprehension of the world and its beings, exploring Goody and Lahire; and, the reflexive form based on the perspective of Dewey's pragmatist philosophy and the pragmatic sociology of Boltanski and Thévenot, in which reflexive action is linked to indeterminacy, where reflexivity is an operation of the intelligence that comes from the organism's contact with an ambiguous environment. After this extensive study, we propose different forms of reflexivity that consist of a high degree of indeterminacy based on people's situations and contexts.

\section{Refererences}

ADAMS, Matthew. Hybridizing habitus and reflexivity: towards an understanding of contemporary identity? Sociology, v. 40, n. 3, p. 511-528, 2006.

ADKINS, Lisa. Reflexivity: freedom or habit of gender? Theory, Culture \& Society, v. 20, n. 6, p. 21-42, 2003.

ARCHER, Margaret S. The reflexive imperative in late modernity. London: Cambridge University Press, 2012.

. Habitus, reflexividade e realismo. Dados - Revista de Ciências Sociais, v. 54, n. 1, p. 157-206, 2011.

Routine, reflexivity, and realism. Sociological Theory, v. 28, n. 3, p. 272-303, 2010.

Making our way through the world: human reflexivity and social mobility. London: Cambridge University Press, 2007. 
Emotions as commentaries on human concerns. Theory and research on human emotions. Advances in Group Processes, v. 21, p. 327-356, 2004.

Structure, agency and the internal conversation. London: Cambridge University Press, 2003.

Being human: the problem of agency. Cambridge, UK: Cambridge University Press, 2000.

BARTHES, Yannick et al. Sociologia pragmática: guia do usuário. Sociologias, n. 41, p. 84-129, 2016.

BECK, Ulrich. Risk society: towards a new modernity. Los Angeles, CA: Sage, 1986.

BECK, Ulrich; GIDDENS, Anthony; LASH, Scott (Orgs.). Modernização reflexiva: política, tradição e estética na ordem social moderna. São Paulo: Editora Unesp, 2000.

BENJAMIN, Walter. Magia e técnica, arte e política. São Paulo: Brasiliense, 1985.

BOLTANSKI, Luc. Énigmes et complots: Une enquête à propos d'enquêtes. Paris: Gallimard. 2012.

. De la critique: précis de sociologie de l'émancipation. Paris: Gallimard, 2009.

. The sociology of critical capacity. European Journal of Social Theory, v. 2, n. 3, pp. 359-377, 1999.

L'amour et la justice comme compétences. Paris: Métailié, 1990.

BOLTANSKI, LUC; CLAVERIE, Elisabeth. Du monde social en tant que scène d'un procès. In: OFFENSTADT, Nicolas; VAN DAMME, Stéphane. Affaires, scandales et grandes causes: de Socrate à Pinochet, p. 395-452. Paris: Stock, 2007.

BOLTANSKI, LUc; THÉVENOT, Laurent. The sociology of critical capacity. European Journal of Social Theory, v. 2, n. 3, p. 359-377, 1999.

De la justification. Les économies de la grandeur. Paris: Gallimard, 1991.

BOURDIEU, Pierre. Masculine domination. Stanford, CA: Stanford University Press, 2001.

BOURDIEU, Pierre; WACQUANT, Loïc. An invitation to reflexive sociology. Chicago, IL; Cambridge, UK: University of Chicago Press; Polity Press, 1992.

BOURDIEU, Pierre et al. A social critique of the judgement of taste. London: Routledge, 1984. 
BOY JD. "The metropolis and the life of spirit" by Georg Simmel: a new translation. Journal of Classical Sociology, v. 21, n. 2, p. 188-202, 2021.

CAETANO, Ana. A exterioridade da reflexividade. Contributos de Lahire para o estudo empírico do exercício de competências reflexivas. Cadernos do Sociofilo, Quarto Caderno: Homenagem a Bernard Lahire, v. 4, n. 1, p. 27-70, 2013.

CARUTH, Cathy (Org.). Trauma: explorations in memory. Baltimore, MD; London: The John Hopkins University Press, 1995.

CEFAÏ, Daniel. Como nos mobilizamos? A contribuição de uma abordagem pragmatista para a sociologia da ação coletiva. Dilemas: Revista de Estudos de Conflito e Controle Social, v. 2, n. 4, p. 11-48, 2009.

CEFAÏ, Daniel; JOSEPH, Isaac (Dirs.). L'héritage du pragmatisme. Conflits d'urbanité et épreuves de civisme. La Tour d'Aigues, FR: Éditions de l'Aube, 2002.

CHALARI, Athanasia. Approaches to the individual. The relationship between internal and external conversation. Manchester (UK): Palgrave Macmillan, 2009.

CHATEAURAYNAUD, Francis. Des prises sur le futur. Regard analytique sur l'activité visionnaire. In: BOURG, Dominque; JOLY, Pierre-Benoît; KAUFMANN, Alain (Dirs.). Retour sur la société du risque - Actes du colloque de Cerisy, 2012.

Argumenter dans un champ de forces: essai de balistique sociologique. Paris: Petra, 2011.

Forces et faiblesses de la nouvelle anthropologie des sciences. Critique, v. 47, p. 529-530, 1991a.

La faute professionnelle. Paris : Métailié, 1991b.

CHATEAURAYNAUD, Francis; TORNY, Didier. Les sombres précurseurs. Une sociologie pragmatique de l'alerte et du risque. Paris: Éditions de l’Ehess, 1999.

COOLEY, Charles H. Human nature and the social order. New York; Chicago, IL; Boston, MA: Charles Scribner's Sons, 1902.

CORRÊA, Diogo. Novos rumos da teoria social a partir de três gestos da sociologia pragmática. Revista Brasileira de Ciências Sociais [online], v. 36, n. 105, 2021.

Entre o querer e o não querer: dilemas existenciais de um ex-traficante na perspectiva de uma sociologia dos problemas íntimos. Tempo Social, v. 32, n. 2, p. 175-204, 2020. 
Anjos de fuzil: uma etnografia das relações entre tráfico de drogas e igreja evangélica. Tese (Doutorado) - École des Hautes Études en Sciences Sociales (Ehess), Paris; Universidade do Estado do Rio de Janeiro (Uerj), Rio de Janeiro, 2015.

Do problema do social ao social como problema: elementos para uma leitura da sociologia pragmática francesa. Revista de Ciências Sociais, n. 40, p. 35-62, 2014.

CORRÊA, Diogo; DIAS, Rodrigo de C. The critique and its critical moments: the recent pragmatic turn in French sociology. Current Sociology, v. 68, n. 6, p. 721-737, 2020.

Crítica e os momentos críticos: De la Justification e a guinada pragmática na sociologia francesa. Mana, v. 22, n. 1, p. 67-99, 2016.

DAS, Veena. O ato de testemunhar: violência, gênero e subjetividade. Cadernos Pagu, v. 37, p. 9-41, 2011.

. Life and words. Violence and the descent into the ordinary. Berkeley, CA; Los Angeles, CA; London: University of California Press, 2007.

Trauma and testimony: implications for political community. Anthropological Theory, v. 3, p. 293-307, 2003.

DEWEY, John. Arte como experiência: últimos escritos, 1925-1953. São Paulo: Martins Fontes, 2010.

O desenvolvimento do pragmatismo americano. Scientiæ Studia, v. 5, n. 2, p. 227-43, 2007. Logic: the theory of inquiry. Nova York: Henry Holt, 1938.

DODIER, Nicolas. Agir dans plusieurs mondes. Critique, v. 47, p. 427-458, 529-530, 1991.

DUBET, François. Dimensions et figures de l'expérience étudiante dans l'université de masse. Revue Française de Sociologie, v. 35, n. 4, p. 511-532, 1994.

FLEETWOOD, Steve. Structure, institution, agency, habit, and reflexive deliberation. Journal of Institutional Economics, v. 4, n. 2, p. 183-203, 2008.

FOUCAULT, Michel. A escrita de si. In: O que é um autor?, p. 129-160. Lisboa: Passagens, 1992. 
GARFINKEL, Harold. Studies in ethnomethodology. Englewood Cliffs NJ: Prentice Hall, 1967.

GIDDENS, Anthony. As consequências da modernidade. São Paulo: Editora Unesp, 1991a.

Modernity and self-identity: self and society in the late modern age. Stanford, CA: Stanford University Press, 1991b.

GOODY, Jack; GOODY, John Rankine. The domestication of the savage mind. Cambridge, UK: Cambridge University Press, 1977.

HABERMAS, Jürgen. Racionalidade da ação e racionalização social. In Teoria do agir comunicativo, v. 1. São Paulo: Martins Fontes, 2012.

JAMES, William. Pragmatism: a new name for some old ways of thinking. Cambridge, MA: Harvard University, 1907.

. The principles of psychology, v. I. London: MacMillan and co, Ltd, 1890.

JOSEPH, Isaac; GRAFMEYER, Yves. L'école de Chicago. Naissance de l'écologie urbaine. Paris: Champs Flammarion, 2004.

KAUFMANN, Jean-Claude. A invenção de si: uma teoria da identidade. São Paulo: Instituto Piaget, 2004.

Ego: pour une sociologie de l'individu. Paris: Nathan, 2001.

KOSELLECK, Reinhart. Futuro passado: contribuição à semântica dos tempos históricos. Rio de Janeiro: Contraponto, 2006.

KRACAUER, Siegfried. O ornamento da massa. São Paulo: Cosac Naify, 2009.

LAHIRE, Bernard. La raison scolaire. École et pratiques d'écriture, entre savoir et pouvoir. Paris: Lectures, Les livres, 2008.

Cartographie de la pluralité des mondes de l'écrit. Pratiques et apprentissage de l'écrit dans les sociétés éducatives. Québec, CA: Presses de I'Université Laval, 2006.

From the habitus to an individual heritage of dispositions. Towards a sociology at the level of the individual. Poetics, v. 31, n. 5-6, p. 329-355, 2003.

Le travail sociologique de Pierre Bourdieu. Paris: La Découverte, 2001a. 
La construction de l' "autonomie" à l'école primaire: entre savoirs et pouvoirs. Revue Française de Pédagogie, v. 135, n. 1, p. 151-161, 2001 b.

MCNAY, Lois. Communitarians and feminists: the case of narrative identity. Literature and Theology, v. 16, n. 1, p. 1-95, 2002

MENEZES, Palloma; CORRÊA, Diogo. From disarmament to rearmament: elements for a sociology of critique of the Pacification Police Unit Program. Vibrant - Virtual Brazilian Anthropology, v. 14, n. 3, 2017.

PEIRCE, Charles S. The essential Peirce, v. 2. Indianapolis, IN: Indiana University Press, 1998.

PETERS, Gabriel. O novo espírito da depressão: imperativos de autorrealização e seus colapsos na modernidade tardia. Civitas - Revista de Ciências Sociais, v. 21, n. 1, p. 71-83, 2021.

A solidão dos deprimidos: sobre virada afetiva e depressão. Blog do sociofilo: Blog de teoria social, filosofia \& ciências sociais, 2019. Disponível em: <https:// blogdosociofilo.com/2019/05/21/a-solidao-dos-deprimidos-sobre-virada-afetiva-e-depressao-por-gabriel-peters/>. Acesso em: 10 Jun. 2019.

A ordem social como problema psíquico. Do existencialismo sociológico à epistemologia insana. São Paulo: Annablume, 2017.

Percursos nas teorias das práticas sociais: Anthony Giddens e Pierre Bourdieu. São Paulo: AnnaBlume, 2015.

Habitus, reflexividade e neo-objetivismo na teoria da prática de Pierre Bourdieu. Revista Brasileira de Ciências Sociais, v. 28, n. 83, 2013.

POLLAK, Michel. A gestão do indisível. WebMosaica: Revista do Instituto Cultural Judaico, v. 2, n. 1, pp. 9-49, 2010.

Memoria, olvido, silencio. La producción social de identidades frente a situaciones limite. Buenos Aires: Al Margem, 2006.

. L'experience concentracionnaire: essai sur le maintien de l'identité sociale. Paris: Métailié, 1990.

RICCEUR, Paul. Tempo e narrativa. Campinas: Papirus, 1997.

Love and justice. Philosophy \& Social Criticism, v. 21, n. 5-6, p. 23-39, 1995 a. 
. Intellectual autobiography. The Philosophy of Paul Ricoeur, v. 22, p. 222256, $1995 b$.

Soi-même comme un autre. Paris: Les Éditions du Seuil, 1994.

SCHÜTZ, Alfred. Fenomenologia e relações sociais. Rio de Janeiro: Zahar, 1979.

. On Multiple realities. Philosophy and Phenomenological Research, v. 5, n. 4, p. 533-576, 1945.

SIMMEL, Georg. As grandes cidades e a vida do espírito. Mana, v. 11, n. 2, p. 577591, 2005 [1903].

A metrópole e a vida mental. In: VELHO, Otávio Guilherme (Org.). O fenômeno urbano. Rio de Janeiro: Zahar, 1979.

SWEETMAN, Paul. Twenty-first century dis-ease? Habitual reflexivity or the reflexive habitus. The Sociological Review, v. 51, n. 4, p. 528-549, 2003.

TALONE, Vittorio. A força da memória: lembranças de situações de ferimento, tensão e morte. Tese (Doutorado) - Instituto de Estudos Sociais e Políticos (lesp) da Universidade do Estado do Rio de Janeiro (Uerj), 2020.

TAYLOR, Charles. Sources of the self. The making of modern identity. Cambridge, UK: Cambridge University Press, 1989.

THÉVENOT, Laurent. L'action au pluriel: Sociologie des régimes d'engagement. Paris: Découverte, 2006. 